\title{
Effect of Phenformin on Substrate Metabolism of Working Muscle in Maturity Onset Diabetics
}

\author{
M. Wicklmayr, G. Dietze, and H. Mehnert \\ III. Medical Department and Diabetes Research Unit, Schwabing City Hospital, Munich, FRG
}

Summary. The effect of biguanides on substrate metabolism of muscle was studied by measurement of arterial and deep venous concentrations of glucose, lactate pyruvate and oxygen and of forearm blood flow in 6 maturity onset diabetics before and after five days of oral phenformin $(150 \mathrm{mg} /$ day $)$.

At rest, substrate balances and forearm blood flow obtained before and after treatment with phenformin did not differ significantly. During work, before treatment, a considerable muscular release of glucose $(-6.64 \pm 2.87 \mu \mathrm{mol} / 100 \mathrm{~g} \cdot \mathrm{min})$, lactate and pyruvate developed, which decreased continuously during recovery. Treatment with phenformin revealed a significant net utilisation of glucose during work $(1.66 \pm 1.87)$ and recovery $(1.62 \pm 0.34)$. An almost identical quantity of lactate and pyruvate continued to be produced during work as before. However, during recovery, lactate release was increased (untreated: $-1.42 \pm 0.67$, treated: $-2.96 \pm 1.08$ ) while pyruvate release was reduced. Accordingly, while before treatment increased deep venous $\mathrm{L} / \mathrm{P}$ ratio slowly normalized during recovery $(12.7 \pm 2.3)$ it persisted after phenformin (29.7 \pm 9.5$)$. Adaptation of muscular oxygen uptake during recovery occurred within 3 minutes before treatment $(8.2 \pm$ 0.3 ), but not even within 5 minutes after treatment $(10.8 \pm 0.5)$. Thus phenformin enhances muscle glucose uptake and lactate release. This peripheral effect may be of clinical importance, since an eightfold increase of muscle lactate and pyruvate release was found in one case of fatal, phenformin-induced lactic acidosis.

Key words: Phenformin, forearm metabolism, lactic acidosis, diabetes.
Biguanides may be assumed to exhibit their blood glucose lowering effect via diminished glucose absorption from the gut $[1,2]$ and reduced hepatic glucose production, at least in part through limited precursor-induced acceleration of gluconeogenesis [3-11]. This latter action is one of the factors which favour the accumulation of blood lactate [11]. Conflicting results, however, have been obtained on peripheral glucose oxidation $[12,13]$ in relation to the development of lactic acidosis during biguanide treatment. Using the forearm method decreased lactate release by resting muscle was found in healthy volunteers [14]; in contrast, in vitro studies showed increased muscle lactate output [15-18]. Similarly, peripheral glucose uptake which was found to be lessened in healthy man [14], was unchanged [19] or increased [20] in maturity onset diabetics. These contradictory data may have been partly due to different experimental techniques and methods of biguanide administration.

One possibility is that biguanides act through inhibition of oxidative phosphorylation [15, 21]. We have therefore investigated their effect on muscle metabolism during work, when energy demand is high and increased substrate oxidation is essential.

\section{Material and Methods}

\section{Subjects}

Six maturity-onset diabetics were recruited from hospitalized patients of the $3^{\text {rd }}$ Medical Department of the Schwabing City Hospital. All were informed about the aim and the risks of the study and gave their consent. The protocol for this study was reviewed and approved by the Investigation- and Ethical-Committee of the Sonderforschungsbereich 51 of the Deutsche Forschungsgemeinschaft according to the code of ethics of the World Medical Association [22]. 
Table 1. Clinical data

\begin{tabular}{|c|c|c|c|c|c|c|c|c|c|}
\hline \multirow[b]{2}{*}{ Name } & \multirow[b]{2}{*}{ Sex } & \multirow[b]{2}{*}{$\begin{array}{l}\text { Age } \\
\text { (years) }\end{array}$} & \multirow[b]{2}{*}{$\begin{array}{l}\text { Height } \\
(\mathrm{cm})\end{array}$} & \multirow[b]{2}{*}{$\begin{array}{l}\text { Percent of } \\
\text { ideal weight } \\
0-\%\end{array}$} & \multirow[b]{2}{*}{$\begin{array}{l}\text { Duration of } \\
\text { diabetes } \\
\text { (years) }\end{array}$} & \multicolumn{4}{|l|}{ Treatment } \\
\hline & & & & & & $\begin{array}{l}\text { Daily } \\
\text { oral } \\
\text { drugs }^{b}\end{array}$ & $\begin{array}{l}\text { Dietary } \\
\text { regimen } \\
(\mathrm{KJ})\end{array}$ & $\begin{array}{l}\text { Serum triglycerides } \\
\mathrm{mg} / 100 \mathrm{ml}\end{array}$ & $\begin{array}{l}\text { Serum cholesterol } \\
\mathrm{mg} / 100 \mathrm{ml}\end{array}$ \\
\hline B. E. & $F$ & 72 & 158 & 114 & 16 & $15 \mathrm{mg} \mathrm{G}$ & 5852 & 198 & 248 \\
\hline F. J. & $\mathbf{M}$ & 69 & 176 & 97 & 6 & $5 \mathrm{mg} \mathrm{G}$ & 6688 & 124 & 188 \\
\hline R. K. & M & 71 & 170 & 127 & 4 & $1 \mathrm{~g} \mathrm{~T}$ & 4180 & 449 & 170 \\
\hline H. E. & $\mathbf{M}$ & 75 & 164 & 97 & 7 & $7.5 \mathrm{mg} \mathrm{G}$ & 6688 & 190 & 264 \\
\hline S. K. & $\mathrm{F}$ & 69 & 155 & 100 & 1 & - & 6688 & 272 & 258 \\
\hline J. W. & M & 60 & 165 & 99 & 0.5 & - & 6688 & 168 & 203 \\
\hline $\begin{array}{l}\text { mean } \pm \\
\text { SEM }\end{array}$ & & $69 \pm 2$ & $165 \pm 3$ & $106 \pm 5$ & $6 \pm 2$ & & $6128 \pm 410$ & $233 \pm 47$ & $222 \pm 16$ \\
\hline R. E. & $F$ & 64 & 165 & 127 & 6 & $100 \mathrm{mg} \mathrm{P}$ & - & - & - \\
\hline
\end{tabular}

${ }^{\text {a }}$ From the Metropolitan Life Insurance Tables, 1959

b G: Glibenclamide, T: Tolbutamide, P: Phenformin

c $45 \%$ Carbohydrates, $20 \%$ Protein and $35 \%$ Fat

d Values after an overnight fast

Clinical data concerning age, weight etc. are presented in Table 1. Physical examination as well as laboratory tests performed in the Department of Clinical Chemistry of the Schwabing City Hospital excluded other internal diseases, though patients B.E. and H. E. had coronary heart disease and were receiving treatment with digitalis, spironolactone and isosorbitol dinitrate. The other patients were on no drugs besides their antidiabetic therapy. There were no gross lipid disturbances except in patient $R . K$.

Diabetes was treated with a dietary regimen and, when necessary, with sulphonylureas for one week at the dose used before admission. The first measurement of muscle metabolism was performed after an overnight fast, 24 hours after the last oral antidiabetic therapy. Patients received no premedication. Thereafter, in addition to the previous antidiabetic treatment $50 \mathrm{mg}$ of phenformin (Dipar ${ }^{\sqrt{(8)}}$, Boehringer Mannheim, FRG) were given three times daily for 5 days and the second study of muscle metabolism performed. Again, treatment with sulphonylureas was withheld for $24 \mathrm{~h}$, but phenformin treatment was continued and $50 \mathrm{mg}$ were given $1-2 \mathrm{~h}$ prior to the test.

During the course of diagnostic blood sampling muscle substrate balances were obtained from one diabetic suffering from lactic acidosis (R. E., Table 1) who had been treated for two years with diet and $100 \mathrm{mg}$ phenformin daily. Besides $2 \times 1$ tablets Modenol $^{\circledR}$ (Boehringer Mannheim, FRG, one tablet containing $3.3 \mathrm{mg}$ butizide, $0.07 \mathrm{mg}$ reserpine, $0.07 \mathrm{mg}$ rescinnamine, $0.7 \mathrm{mg}$ raubasine and $300 \mathrm{mg}$ potassium chloride) for hypertension and $3 \times 0.125 \mathrm{mg}$ digoxin for myocardiad failure per day no other drugs had been given to the patient. A few days before admission the patient developed increasing gastric and intestinal discomfort, vomitus and fatigue. On admmission she was comatose and was not in manifest heart failure. The diagnosis of lactic acidosis was confirmed by an arterial lactate level of $14.8 \mathrm{mmol} / 1$ and blood $\mathrm{pH}$ of 6.96 . The level of haemoglobin was $13.1 \mathrm{~g} / 100 \mathrm{ml}$. Further details have been published elsewhere [23].

\section{Catheterization, Blood Sampling and Measurement of Forearm} Muscle Blood Flow

All studies were performed between $8.30 \mathrm{a} . \mathrm{m}$. and $11.30 \mathrm{a} . \mathrm{m}$. with the subjects recumbent. Special care was taken to ensure that the arm rested comfortably in a horizontal position and that room temperature remained constant. Under sterile conditions and local anaesthesia a Cournand-needle (Size: PE 160, Kifa, Sweden) was inserted into the right femoral artery, and flushed continuously with $\mathrm{NaCl}(0.154 \mathrm{~mol} / \mathrm{l})$ containing small amounts of heparin at a rate $(0.05 \mathrm{U} / \mathrm{kg}$ body weight $\mathrm{x} \mathrm{min})$ which guaranteed no significant effect on lipoprotein lipase activity [24]. Thereafter, one of the cubital veins probably draining deep tissues of the forearm was cannulated and a teflon catheter (Code 11512, Vygon, France) inserted as deeply as possible, $i$. e. when the tip of the catheter could no longer be palpated, $\mathrm{X}$-ray examination confirmed a position in deep forearm tissue and the arterial-deep venous oxygen difference exceeded $2.5 \mathrm{mmol} / \mathrm{l}$. Special care was taken that during the second experiment the same position was obtained as during the first study. After an equilibration period of 15 minutes arterial and deep venous blood samples were taken at 10 minute intervals during a $30 \mathrm{~min}$ basal period and at 30 second intervals during an one minute half-maximal rhythmic handgrip work $(5 \mathrm{kpm} / \mathrm{min})$, standardized by a special ergometer [25], and at 1.3 and 5 minutes during recovery.

Immediately after sampling $2 \mathrm{ml}$ of blood were mixed with $6 \mathrm{ml}$ of icecold $0.6 \mathrm{~mol} / 1$ perchloric acid and centrifuged at $4{ }^{\circ} \mathrm{C}$. After neutralization with $\mathrm{KHCO}_{3}$ the supernatants were analyzed as quickly as possible for pyruvate. Glucose, lactate and alanine were determined after storage overnight at $-20^{\circ} \mathrm{C}$. Blood samples for oxygen were taken in heparinized syringes and analyzed immediately.

Forearm blood flow was measured during the basal period by venous occlusion plethysmography [26] and, additionally, during the basal period, exercise and recovery by the ${ }^{133}$ Xenon injection technique [27].

In the case of the lactic acidosis patient only two arterial and deep-venous blood samples were taken at a 2 minute interval and blood flow of the forearm was measured by venous occlusion technique before any therapy was started. The commencement of therapy was not delayed, since this procedure was finished within 5-10 min. During this time a central venous catheter was inserted from the other arm and therapy was started immediately after the second blood sample. Blood pressure was found to be $110 / 80 \mathrm{~mm}$ $\mathrm{Hg}$ when blood samples were obtained.

\section{Analyses}

Glucose, lactate, pyruvate and alanine were determined enzymatically [28-31], and oxygen was determined oxymetrically [32]. Precision of the methods has been given elsewhere [33]. Substrates in each blood sample were determined at least in duplicate. The basal values represent the mean of four determinations obtained at 10 
minute intervals before exercise was started. Wilcoxon's rank test was applied to the results [34]. A significant difference was assumed at $\mathrm{p}<0.05$. All mean values are given with the standard error of the mean (SEM). Substrate uptake was calculated according to Fick [35] by multiplying the blood flow rates obtained with the ${ }^{133}$-Xenon-technique during basal period, exercise and recovery with the corresponding arterial-deep-venous substrate differences.

\section{Materials}

Radioactive ${ }^{133}$ Xenon (Radiochemical Centre, Amersham, Great Britain) was purchased as a sterile solution of $2 \mathrm{Ci} / \mathrm{cm}^{3}$. Heparin was used as a sterile solution of sodium heparinate containing 5000 USP U/ml (Hoffmann-La Roche, Grenzach, FRG).

\section{Results}

\section{Effect of Phenformin Treatment on Arterial Concentrations and Balances of Substrates}

a) At Rest (Table 2): As expected in maturity-onset diabetics arterial glucose concentration was significantly decreased with phenformin therapy compared to pretreatment values. Alanine concentration was found to be elevated with phenformin. The arterial levels of lactate, pyruvate and oxygen remained unchanged after phenformin treatment.

No significant changes were found for the arterial-deep venous differences of glucose, lactate, pyruvate, alanine and oxygen. Plethysmography showed no effect of phenformin on the rate of blood flow of the forearm.

b) During Muscular Work and Recovery (Tables 3 and 4): During the short period of work (1 min) and during recovery $(5 \mathrm{~min}$ ) the arterial concentrations of oxygen and of the substrates remained constant.

During rhythmic forearm exercise the same increase of muscular blood flow was obtained using the ${ }^{133}$ xenon-injection-technique with and without phenformin. During recovery, blood flow also decreased to the same extent. Since blood flow was not influenced by phenformin, the observed differences in substrate utilisation (Table 4) were exclusively due to the changed balances, which are indicated in Table 3.

Table 2. Arterial concentrations (A) and arterial - deep venous differences (AVD) of glucose, lactate, pyruvate, alanine and oxygen and blood flow of the resting forearm in maturity onset diabetics before and after treatment with phenformin

\begin{tabular}{llrc}
\hline & & Untreated & After phenformin \\
\hline Glucose $^{\mathrm{a}}$ & $\mathrm{A}$ & $7.51 \pm 0.83$ & $5.82 \pm 0.54^{\mathrm{c}}$ \\
& $\mathrm{AVD}$ & $-0.06 \pm 0.18$ & $0.15 \pm 0.04$ \\
Lactate $^{\mathrm{a}}$ & $\mathrm{A}$ & $0.57 \pm 0.04$ & $0.64 \pm 0.07$ \\
& $\mathrm{AVD}$ & $-0.05 \pm 0.02$ & $-0.07 \pm 0.01$ \\
Pyruvate $^{\mathrm{a}}$ & $\mathrm{A}$ & $0.047 \pm 0.005$ & $0.047 \pm 0.007$ \\
& $\mathrm{AVD}$ & $-0.019 \pm 0.004$ & $-0.011 \pm 0.002$ \\
Alanine $^{\mathrm{a}}$ & $\mathrm{A}$ & $0.18 \pm 0.02$ & $0.22 \pm \ldots \mathrm{c}$ \\
& $\mathrm{AVD}$ & $-0.02 \pm 0.01$ & $-0.05 \pm 0.02$ \\
Oxygen $^{\mathrm{a}}$ & $\mathrm{A}$ & $8.4 \pm 0.1$ & $8.4 \pm 0.1$ \\
& $\mathrm{AVD}$ & $3.6 \pm 0,4$ & $3.5 \pm 0.3$ \\
Blood flow $^{\mathrm{b}}$ & & $3.2 \pm 0.3$ & $3.1 \pm 0.2$
\end{tabular}

The values represent the mean \pm SEM of 6 subjects in ${ }^{a} \mathrm{mmol} / 1$ and in ${ }^{b} \mathrm{ml} / 100 \mathrm{~g} \cdot \min$ (Measured by venous occlusion plethysmography). For each subject 4 samples obtained at 10 min intervals were averaged.

c Significant difference after phenformin compared with untreated ( $p<0.05$, according to rank order) - : Indicates release

Table 3. Arterial-deep venous differences of glucose, lactate, pyruvate and oxygen, muscle blood flow and deep-venous lactate/pyruvate ratio in maturity onset diabetics before $(\mathrm{U})$ and after treatment $(\mathrm{P})$ with phenformin during rhythmic isometric forearm exercise $(1$ min) and during recovery $(5 \mathrm{~min})$

\begin{tabular}{|c|c|c|c|c|c|c|c|c|}
\hline & & \multicolumn{2}{|l|}{ Exercise } & \multicolumn{5}{|l|}{ Recovery } \\
\hline & & $0.5 \mathrm{~min}$ & $1 \mathrm{~min}$ & $1 \mathrm{~min}$ & \multicolumn{2}{|l|}{$3 \min$} & \multicolumn{2}{|l|}{$5 \mathrm{~min}$} \\
\hline \multirow[t]{2}{*}{ Glucose $^{\mathrm{a}}$} & $\mathrm{U}$ & $-0.26 \pm 0.27$ & $-0.60 \pm 0.19$ & $-0.41 \pm 0.15$ & -0.27 & \pm 0.20 & -0.01 & \pm 0.11 \\
\hline & $\mathbf{P}$ & $0.27 \pm 0.19$ & $0.12 \pm 0.16^{\mathrm{d}}$ & $0.38 \pm 0.14^{d}$ & 0.49 & $\pm 0.14^{\mathrm{d}}$ & 0.57 & $\pm 0.12^{\mathrm{d}}$ \\
\hline \multirow[t]{2}{*}{ Lactate $^{a}$} & $\mathrm{U}$ & $-0.67 \pm 0.15$ & $-1.10 \pm 0.15$ & $-0.88 \pm 0.23$ & -0.63 & \pm 0.23 & -0.43 & \pm 0.20 \\
\hline & $\mathbf{P}$ & $-0.69 \pm 0.20$ & $-1.21 \pm 0.25$ & $-1.16 \pm 0.32$ & -1.14 & $\pm 0.32^{\mathrm{d}}$ & -0.97 & $\pm 0.35^{\mathrm{d}}$ \\
\hline \multirow[t]{2}{*}{ Pyruvate $^{\mathrm{a}}$} & $\mathbf{U}$ & $-0.051 \pm 0.017$ & $-0.058 \pm 0.012$ & $-0.042 \pm 0.008$ & -0.04 & $5 \pm 0.011$ & -0.039 & $9 \pm 0.012$ \\
\hline & $\mathbf{P}$ & $-0.041 \pm 0.005$ & $-0.038 \pm 0.007$ & $-0.023 \pm 0.010$ & -0.023 & $3 \pm 0.011^{\mathrm{d}}$ & -0.020 & $0 \pm 0.010^{d}$ \\
\hline \multirow[t]{2}{*}{ Oxygen $^{a}$} & $\mathrm{U}$ & $-\mathrm{c}$ & $-\mathrm{c}$ & $4.4 \pm 0.3$ & 2.9 & \pm 0.4 & 2.8 & \pm 0.3 \\
\hline & $\mathrm{P}$ & $-^{c}$ & $--^{c}$ & $4.8 \pm 0.3$ & 3.9 & $\pm 0.4^{\mathrm{d}}$ & 3.8 & $\pm 0.3^{\mathrm{d}}$ \\
\hline \multirow[t]{2}{*}{ Blood flow } & $\mathbf{U}$ & $11.0 \pm 2.0$ & & & 3.1 & \pm 0.3 & & \\
\hline & $\mathrm{P}$ & $10.6 \pm 1.6$ & & & 2.9 & \pm 1.6 & & \\
\hline \multirow[t]{2}{*}{$\mathrm{L} / \mathrm{P}$ ratio } & $\mathbf{U}$ & $13.7 \pm 1.7$ & \pm 2.6 & \pm 2.3 & 13.4 & \pm 1.8 & 12.7 & \pm 2.3 \\
\hline & $\mathbf{P}$ & $16.0 \pm 2.2$ & $\pm 2.6^{\mathrm{d}}$ & $31.7 \pm 10.0^{\mathrm{d}}$ & 32.7 & $\pm 10.5^{\mathrm{d}}$ & 29.7 & $\pm 9.5^{\mathrm{d}}$ \\
\hline
\end{tabular}

The values represent the mean \pm SEM of 6 subjects in ${ }^{a} \mathrm{mmol} / \mathrm{l}$ and in ${ }^{\mathrm{b}} \mathrm{ml}$ per $100 \mathrm{~g}$ of muscle weight per minute (Measured with the ${ }^{133}$ Xenoninjection technique)

${ }^{c}$ not measured

d Significant difference after phenformin compared with the value obtained without treatment $(\mathrm{p}<0.05$, according to rank order)

- : Indicates release 
Table 4. Muscle uptake of glucose, lactate, pyruvate and oxygen in maturity onset diabetics before (U) and after treatment (P) with phenformin during a basal period, rhythmic isometric forearm exercise $(1 \mathrm{~min})$ and during recovery $(5 \mathrm{~min})$

\begin{tabular}{|c|c|c|c|c|c|}
\hline & & \multirow[t]{2}{*}{ Basal } & \multirow{2}{*}{$\begin{array}{l}\text { Exercise } \\
1 \mathrm{~min}\end{array}$} & \multicolumn{2}{|l|}{ Recovery } \\
\hline & & & & $3 \min$ & $5 \min$ \\
\hline \multirow[t]{2}{*}{ Glucose } & $\mathrm{U}$ & $-0.16 \pm 0.46$ & $-6.64 \pm 2.87$ & $-0.77 \pm 0.59$ & $-0.03 \pm 0.37$ \\
\hline & $P$ & $0.40 \pm 0.10$ & $1.66 \pm 1.87^{\mathrm{a}}$ & $1.38 \pm 0.39^{a}$ & $1.62 \pm 0.34^{a}$ \\
\hline \multirow[t]{2}{*}{ Lactate } & $\mathrm{U}$ & $-0.14 \pm 0.05$ & $-10.60 \pm 1.94$ & $-2.01 \pm 0.77$ & $-1.42 \pm 0.67$ \\
\hline & $P$ & $-0.17 \pm 0.03$ & $-11.96 \pm 3.02$ & $-3.44 \pm 0.98^{\mathrm{a}}$ & $-2.96 \pm 1.08^{\mathrm{a}}$ \\
\hline \multirow[t]{2}{*}{ Pyruvate } & $\mathrm{U}$ & $-0.047 \pm 0.009$ & $-0.599 \pm 0.112$ & $-0.129 \pm 0.027$ & $-0.113 \pm 0.036$ \\
\hline & $P$ & $-0.029 \pm 0.005$ & $-0.421 \pm 0.127$ & $-0.071 \pm 0.035$ & $-0.059 \pm 0.031^{\mathrm{a}}$ \\
\hline \multirow[t]{2}{*}{ Oxygen } & $U$ & $9.2 \pm 0.6$ & - & $8.4 \pm 0.3$ & $8.2 \pm 0.3$ \\
\hline & $\mathbf{P}$ & $9.1 \pm 0.5$ & - & \pm 0.6 & $10.8 \pm 0.5$ \\
\hline
\end{tabular}

The values represent the mean \pm SEM of 6 subjects in $\mu$ mol per $100 \mathrm{~g}$ of muscle weight per minute. Blood flow was measured with the ${ }^{133}$ Xenon injection technique. During the basal period for each subject four samples obtained at 10 min intervals were averaged and used for calculation.

${ }^{a}$ Significant difference after phenformin compared with untreated ( $\mathrm{p}<0.05$, according to rank order)

- : Indicates release

Before treatment, glucose release during rest was significantly increased during work, and returned continuously to basal during recovery. After treatment with phenformin, glucose uptake was observed during work rather than glucose release. This continued during recovery. Lactate production was increased likewise with and without pretreatment during muscle work. However, during recovery after treatment, this increased lactate output returned more gradually towards normal. On the contrary, pyruvate output decreased more rapidly after phenformin. Accordingly, the deep venous L/P-ratio, which before treatment increased during muscular work and decreased continuously during recovery, showed a much greater increase during work after phenformin and remained elevated during recovery.

Before treatment, no difference in muscle oxygen uptake from basal values was observed during the recovery phase. However, after phenformin treatment oxygen uptake was found to be elevated during recovery.

\section{Substrate Balances of the Resting Muscle in One Case of Fatal Lactic Acidosis}

In patient R.E. (Table 1), arterial lactate was $14.8 \mathrm{mmol} / \mathrm{l}$ and pyruvate $0.19 \mathrm{mmol} / 1$. Immediately before therapy, arterial-deep venous balances for lactate were -0.95 and for pyruvate $-0.13 \mathrm{mmol} / \mathrm{l}$. The perfusion of the forearm was $2.2 \mathrm{ml} / 100 \mathrm{~g} \cdot \mathrm{min}$ as obtained by venous occlusion plethysmography. For comparison, the corresponding normal values in maturity onset diabetics are listed up in Table 2.

\section{Discussion}

In the present study five days pretreatment with phenformin was employed since it has become evi- dent that this regimen leads to cellular concentrations similar to those effective in vitro [36, 37]. Nevertheless, no significant changes of glucose utilization and $\mathrm{C}_{3}$-body production of the muscle were observed during resting conditions (Table 2). However, since the same amount of glucose was taken up at a lower arterial concentration, an increased fractional extraction of glucose was obvious. This finding corresponds to earlier results [38] demonstrating that biguanides lower the threshold for glucose entry into the muscle cell. Biguanides are known to accelerate glycogenolysis [18]. While, in general, glycogen stores are reduced during muscular work and are restored again during rest, one would expect under biguanide treatment that depletion of the glycogen stores would be more intensive and restoration slowlier. Since changes in the rate of glycogenolysis may effect glucose uptake of muscle [39-42] one would also expect to find, with biguanides, corresponding to the overwhelming of glycogen breakdown or synthesis, either reduced glucose uptake, as was found in healthy volunteers [14], or enhanced glucose uptake as was found in the diabetic state $[20,38]$, when glycogen stores are more rapidly depleted [43]. According to these findings one might suggest that the increased fractional extraction of glucose by muscle found in this study could also be due to a prolonged restoration of the glycogen stores caused by the preceding depletion. Since there were no enzymes found to be influenced by biguanides [7] acceleration of glycogenolysis was suggested to be due to the wellknown inhibitory action of the biguanides on electron transport and oxidative phosphorylation $[15,21]$. If this were also true in the model presented, a greater portion of the glucose taken up should leave the muscle again as lactate. This was not the case under resting conditions. Since decreased availability of glucose from depleted glycogen stores and inhibition of elec- 
tron transport should become more obvious when energy demand rises, we have employed short and mild muscular exercise. Indeed, this procedure, which reduced glucose uptake in normal [44] and exhibited even glucose output in diabetic subjects (Table 3), resulted in acceleration of glucose entry under the influence of phenformin. From the data presented here it is difficult to decide whether this effect is due to decreased intracellular availability of glucose or to impaired electron transport. The unchanged rates of lactate output during work support the first possibility. However, one has to take into account that lactate usually accumulates within the muscle until its production rates are found to be increased $[45,46]$. This could play a role, since work was short and mild and lactate production was indeed larger during recovery. Furthermore, increased deep venous lactate/pyruvate ratio and oxygen consumption during recovery would also support the view that a greater energy lack during work is also at least partly responsible for the accelerated glucose uptake observed. This view receives support from results obtained with the isolated hind limb, which show greater reduction of the creatine phosphate content during work after phenformin pretreatment [47].

From these findings one can conclude that the effect of biguanides on muscle glucose uptake and consequently on blood glucose concentration may not entirely be unconnected with increased production of lactate. Taking into account that there is also impaired hepatic lactate uptake under biguanide treatment $[10,11]$ one may expect disturbance of lactate homeostasis at least under certain conditions leading to accelerated lactate production. That enhanced peripheral production of lactate may be one of the factors which are responsible for the occurrence of fatal lactic acidosis is underlined by the increased rates of muscle lactate output obtained in one case suffering from this complication (see Results 2).

Acknowledgement. We are indebted to E. A. Bauer, E. Müller, E. Maerker, M. L. Kirschner and G. Trotleff for their expert technical assistance. This work was supported by a grant from the Deutsche Forschungsgemeinschaft, SFB 51, Munich.

\section{References}

1. Czyzyk, A., Tawecki, J., Sadowski, J., Ponikowska, I., Szczempanik, Z.: Effect of biguanides on intestinal absorption of glucose. Diabetes 17, 492-498 (1968)

2. Berger, W., Künzli, H.: Effect of dimethylbiguanide on insulin, glucose and lactic acid contents observed in portal vein blood and peripheral venous blood in the course of intraduodenal glucose tolerance tests. Diabetologia 4, 382 (1968)

3. Patrick, S. J.: Effect of phenformin and hypoglycin on gluconeogenesis of rat tissues. Can. J. Biochem. 44, 27-33 (1966)

4. Mayer, F., Ipaktchi, M., Clauser, H.: Specific inhibition of gluconeogenesis by biguanides. Nature 213, 203-204 (1967)

5. Altschuld, R. A., Krüger, F. A.: Inhibition of hepatic gluconeogenesis in guinea pig by phenformin. Ann. N. Y. Acad. Sci. 148, 612-622 (1968)

6. Creutzfeld, W., Willms, B., Caspary, W.: The mechanism of action of the blood glucose lowering biguanides. In (Ed.): R. R. Rodriguez, J. Vallance-Owen, Diabetes (Proc. $7^{\text {th }}$ Congr. Int. Diab. Fed.) pp. 708-719. Amsterdam: Excerpta Medica 1971

7. Haeckel, R., Haeckel, H.: Inhibition of gluconeogenesis from lactate by phenethylbiguanide in the perfused guinea pig liver. Diabetologia 8, 117-124 (1972)

8. Nielsen, R. L., Swanson, H. E., Tanner, D. C., Williams, R. H., Connell, M.: Effects on blood sugar of a new potent hypoglycemic compound. Arch. Intern. Med. 101, 211-216 (1958)

9. Beringer, A., Hupka, K., Mosslacher, K., Moser, K., Wenger, R.: Zur Beeinflussung des menschlichen Diabetes mit Insulin, blutzuckersenkenden Sulfonamiden sowie Biguaniden. Wien. Med. Wochenschr. 108, 639-644 (1958)

10. Mehnert, H.: The Biguanides: Mechanism of action and clinical application. In (Ed.): W. J. Malaisse, J. Pirart, Diabetes. International Congress Series No. 312. Proceedings of the Eighth Congress of the International Diabetes Federation, Brüssel, July 15-20, 1973. Amsterdam: Excerpta Medica 1973

11. Dietze, G., Wicklmayr, M., Mehnert, H., Czempiel, H., Henftling, H. G.: Effect of phenformin on hepatic balances of gluconeogenic substrates in man. Diabetologia 14, 243-248 (1978)

12. Kreisberg, R. A.: Glucose metabolism in normal and obese subjects. Effect of phenformin. Diabetes 17, 481-487 (1968)

13. Searle, G. L., Gulli, R., Cavalieri, R. R.: Effect of phenformin in nondiabetic humans, estimation of glucose turnover rate and Cori cycle activity. Metabolism 18, 148-154 (1969)

14. Dietze, G., Wicklmayr, M., Braun, S., Hepp, K. D., Mehnert, H.: Untersuchungen zur Wirkung von Biguaniden am Gesunden. Die Glukoseutilisation des Muskels unter dem Einfluß von Phenformin. Verh. Dtsch. Ges. Inn. Med. 80, 1283-1286 (1974)

15. Steiner, D.F., Williams, R. H.: Respiratory inhibition and hypoglycemia by biguanides and decamethylene-diguanide. Biochim. Biophys. Acta 93, 279-283 (1964)

16. Strohfeldt, P., Meißner, H. P., Weinges, K.F.: The effect of buformin upon blood glucose level of normal rats and carbohydrate metabolism of the isolated rat diaphragm. Diabetologia 8, 377-380 (1972)

17. Ungar, G., Freedman, L., Shapiro, S. L.: Pharmacological studies of a new oral hypoglycemic drug. Proc. Exp. Biol. 93, 190-196 (1957)

18. Tyberghein, J.M., Williams, R. H.: Metabolic effects of phenethylbiguanide, a new hypoglycemic compound. Proc. Soc. Exp. Biol. Med. 96, 29-34 (1957)

19. Madison, L. L., Unger, R. H.: Effect of phenformin on peripheral glucose utilization in human diabetic and nondiabetic subjects. Diabetes 9, 202-206 (1960)

20. Butterfield, W. J. H., Whichelow, M. J.: Effect of diet, sulphonylureas and phenformin on peripheral glucose uptake in diabetes and obesity. Lancet $1968 \mathrm{II}, 785-793$

21. Schäfer, G.: Site-specific uncoupling and inhibition of energy transfer by biguanides. Biochim. Biophys. Acta 93, 279-283 (1964)

22. World Medical Association; Declaration of Helsinki. Br. Med. J. 1964 II, 177-180

23. Haslbeck, M., Wittmann, P., Bachmann, W., Mehnert, H.: Verlauf, Therapie und diagnostische Probleme bei 
Diabetikern mit Laktazidose nach Biguanidbehandlung. Infusionstherapie (in press)

24. Boberg, J.: Heparin-released blood plasma lipoprotein lipase activity in patients with hyperlipoproteinemia. Acta Med. Scand. 191, 97-105 (1972)

25. Wahren, J.: Quantitative aspects of blood flow and oxygen uptake in the human forearm during rhythmic exercise. Acta Physiol. Scand. 67 (Suppl. 269), 1-93 (1966)

26. Barbey, K., Barbey, P.: Ein neuer Plethysmograph zur Messung der Extremitätendurchblutung. Z. Kreisl.-Forsch. 52, 1129-1140 (1963)

27. Holzmann, G.B., Wagner, H. N., Rabinowitz, M., Zierler, K. L.: Measurement of muscle blood flow in the human forearm with radioactive krypton and xenon. Circulation 30, 27-36 (1964)

28. Bergmeyer, H. U., Bernt, E., Schmidt, F., Stork, H.: D-Glucose, Bestimmung mit Hexokinase und Glukose-6-PhosphatDehydrogenase. In: H. U. Bergmeyer (Ed.): Methoden der enzymatischen Analyse. Vol. II, P. 1163-1172. Weinheim: Verlag Chemie 1970

29. Hohorst, H. J.: L-(+)-Lactat. In: H. U. Bergmeyer (Ed.): Methoden der enzymatischen Analyse. Vol. II, P. 1425-1429. Weinheim: Verlag Chemie 1970

30. Czok, R., Lamprecht, W.: Pyurvat, Phosphoenolpyruvat und D-Glycerat-2-phosphat. In: H. U. Bergmeyer (Ed.): Methoden der enzymatischen Analyse. Vol. II, P. 1407-1411. Weinheim: Verlag Chemie 1970

31. Williamson, D. H.: L-Alanin. In: H. U. Bergmeyer (Ed.): Methoden der enzymatischen Analyse. Vol. II, P. 1634-1637. Weinheim: Verlag Chemie 1970

32. Zjylstra, W. G.: Reflexionsoxymetrie. In: K. Kramer: Oxymetrie, P. 98-116. Stuttgart: G. Thieme 1960

33. Dietze, G., Wicklmayr, M., Hepp, K.D., Bogner, W., Mehnert, H., Czempiel, H., Henftling, H. G.: On gluconeogenesis of human liver. Accelerated hepatic glucose formation induced by increased precursor supply. Diabetologia 12, 555-561 (1976)

34. Hills, M.: Statistics for comparative purposes. London: Chapman \& Hall 1974

35. Fick, A.: Uber die Messung des Blutquantums in den Herzventrikeln. Physiol. Med. Ges. 2, 16-28 (1970)

36. Beckmann, R.: Resorption, Verteilung im Gewebe und Ausscheidung von 1-Butyl-biguanid 14C-hydrochlorid. Arzneim. Forsch. 15, 761-764 (1965)

37. Wick, A. N., Stewart, Ch. J., Serif, G. S.: Tissue distribution of
$C^{14}$-labeled betaphenethyl-biguanide. Diabetes 9, 163-167 (1960)

38. Butterfield, W. J. H., Whichelow, M. J.: The hypoglycemic action of phenformin. Effect of phenformin on glucose metabolism in peripheral tissues. Diabetes 11, 281-286 (1962)

39. Walaas, O., Walaas, W.: Effect of epinephrine on rat diaphragm. J. Biol. Chem. 187, 769 776 (1950)

40. Boumann, P.R., Dexmer, W.: Effect of adrenaline on carbohydrate metabolism in the isolated diaphragm of intact and adrenalectomized rats as influenced by "nembutal" anaesthesia. Acta Endocrinol. (Kbh.) 35, 541-550 (1960)

41. Saha, J., Lopez-Mondragon, R., Narahara, H. T.: Effect of epinephrine on permeability to sugar and of the production of free glucose in skeletal muscle. J. Biol. Chem. 243, 521-527 (1968)

42. Wicklmayr, M., Dietze, G.: On the mechanism of muscular glucose release in juvenile diabetics in acute insulin deficiency. Eur. J. Clin. Invest. 8, 81-86 (1978)

43. Fisher, N. F., Lackey, R. W.: The glycogen content of the heart, liver and muscles of normal and diabetic dogs. Am. J. Physiol. 72, 43-49 (1925)

44. Jorfeldt, L., Wahren, J.: Human forearm muscle metabolism during exercise. V. Quantitative aspects of glucose uptake and lactate production during prolonged exercise. Scand. J. Clin. Lab. Invest. 26, 73-81 (1970)

45. Saltin, B., Essén, B.: Muscle glycogen, lactate, ATP and CP in intermittent exercise in muscle metabolism during exercise. P. 419-423, B. Pernow and B. Saltin (Eds.). New York: Plenum Publ. 1971

46. Karlsson, J., Rosell, S., Saltin, B.: Carbohydrate and fat metabolism in contracting canine skeletal muscle. Pfluegers Arch. 331, 57-69 (1972)

47. Strohfeldt, P., Strubel, U.: Effect of buformin on muscle energy metabolism. Horm. Metab. Res. 8, 243 (1976)

Received: October 25, 1977,

and in revised form: March 15, 1978

Dr. M. Wicklmayr

III. Department of Medicine

Schwabing City Hospital

Kölner Platz 1

D-8000 München 40

Federal Republic of Germany 